\title{
IMPLEMENTASI PEMANFAATAN MEDIA VISUAL UNTUK KETERAMPILAN BERBICARA PADA PEMBELAJARAN BAHASA ARAB
}

\author{
Thufeyl Vandayo ${ }^{1 *}$ dan Danial Hilmi ${ }^{1}$ \\ ${ }^{1}$ Pascasarjana UIN Maulana Malik Ibrahim Malang
}

\begin{abstract}
This research discusses visual media as an Arabic learning instrument that concentrates on speaking skills. Visual media is a popular medium in the education era 4.0 by the millennial generation. Through a literature review, the research describes important points in the use of visual media: the category of visual media, the principles of using visual media, guidelines in designing visual media and their implementation in Arabic learning. The purpose of using visual media is to increase students' enthusiasm for learning and increase teacher innovation and creativity in teaching. Some visual media that teachers can use in the learning process of Arabic speaking skills include: wall clocks, bulletin boards, flannel boards, posters and pictures. The concepts and principles of using visual media need to be considered, so that the process of using visual media in learning is effective and optimal.
\end{abstract}

Keywords: Visual media, Speaking skill, Arabic Learning

*Korespondensi Penulis: thufeylvandayo@gmail.com 


\begin{abstract}
Abstrak: Penelitian membahas tentang media visual sebagai instrumen pembelajaran bahasa Arab yang berkonsentrasi pada keterampilan berbicara. Media visual merupakan media yang populer di era pendidikan 4.0 oleh generasi milenial. Melalui kajian literatur, penelitian memaparkan poin-poin penting dalam pemanfaatan media visual: kategori media visual, prinsip-prinsip penggunaan media visual, pedoman dalam merancang media visual serta implementasinya dalam pembelajaran bahasa Arab. Tujuan penggunaan media visual adalah untuk meningkatkan semangat siswa dalam belajar serta meningkatkan inovasi dan kreativitas guru dalam mengajar. Beberapa media visual yang dapat digunakan guru dalam proses pembelajaran keterampilan berbicara bahasa Arab antara lain: jam dinding, papan buletin, papan flanel, poster dan gambar. Konsep dan prinsip penggunaan media visual perlu diperhatikan, agar proses penggunaan media visual dalam pembelajaran menjadi efektif dan optimal.
\end{abstract}

\title{
Kata Kunci: Media Visual, Ketrampilan Berbicara, Pembelajaran Bahasa Arab
}

\section{A. Pendahuluan}

Tidak berbeda dengan proses pembelajaran lainnya, dalam pembelajaran bahasa, seorang guru juga dituntut untuk memiliki skill dalam menggali kreatifitasnya. Implementasi kreatifitas tersebut dalam prosesnya tentu membutuhkan inovasi pembelajaran yang diharapkan dapat menarik perhatian siswa. Dan tentunya dengan bantuan media, pembelajaran bahasa akan menjadi semakin menarik, mudah dan menyenangkan. Media pembelajaran berfungsi sebagai salah satu proses pendukung pembelajaran yang dapat memfasilitasi pendidik dalam penyampaian materi pelajaran kepada siswa. Manfaat lain dari media pembelajaran adalah sebagai solusi dalam meningkatkan antusiasme dan minat siswa dalam proses belajar. Namun, tentunya tidak semua jenis media dapat diterapkan dalam semua keterampilan bahasa, sehingga dibutuhkan ketelitian 
seorang pendidik dalam memilih media mana yang cocok dan mendukung dalam penyampaian materi pelajaran. ${ }^{1}$

Proses pembelajaran dapat dikatakan menarik apabila ia memiliki unsur "gelitik" bagi siswa. Hingga kemudian siswa memiliki motivasi untuk terus mengikuti proses pembelajaran. Pembelajaran juga dapat dikatakan menyenangkan apabila ia sepadan dan serasi dengan suasana yang terjadi pada siswa. ${ }^{2}$ Ibrahim Nashir menyampaikan dalam Fi Muqaddimati at-Tarbiyah mengenai pemahaman media pembelajaran sebagai berikut, yakni:

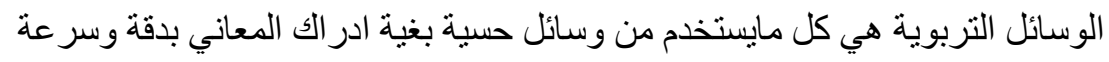

"Media pembelajaran merupakan metode kongkrit yang digunakan untuk memahami makna secara akurat dan cepat."

Dalam proses pembelajaran, beberapa fungsi media antara lain sebagai perangkat untuk menyampaikan informasi sehingga dapat mempermudah proses belajar mengajar, menambah ketertarikan siswa sehingga motivasi mereka meningkat untuk belajar mereka dan juga media pembelajaran juga berperan sebagai solusi keterbatasan sensorik, ruang dan waktu. ${ }^{3}$

Secara umum media pembelajaran memiliki beberapa jenis, diantaranya adalah media berbasis audio, visual, audio-visual, komputer dan lainnya. Namun dalam penelitian ini penulis akan fokus pada media pembelajaran berbasis visual. Ada berbagai konsep dan prinsip dasar yang perlu diperhatikan dalam penggunaan media visual agar dalam penggunaannya menjadi lebih optimal. Ini merupakan sebuah acuan dasar dari pemilihan sebuah media, sehingga peran media sebagai alat untuk memfasilitasi proses pembelajaran yang akan

1 Jepri Nugrawiyati, “Media Audio-Visual Dalam Pembelajaran Bahasa Arab,” ElWasathiya: Jurnal Studi Agama 6, no. 1 (2018): 97-111.

2 Syaiful Mustofa, Strategi Pembelajaran Bahasa Arab Inovatif (Malang: UIN-Maliki Press, 2011).

3 Ali Muhson, "Pengembangan media pembelajaran berbasis teknologi informasi," Jurnal Pendidikan Akuntansi Indonesia 8, no. 2 (2010). 
disampaikan dapat dimanfaatkan secara maksimal.4 Oleh sebab itu, dalam penerapannya terhadap proses pembelajaran Bahasa Arab, perlu adanya pembahasan yang lebih mendalam mengenai prinsip-prinsip media visual.

Berbagai macam teknik dan model pembelajaran pada materi percakapan telah banyak dikembangkan oleh guru-guru bahasa. Setiap metode atau pendekatan tersebut tentu saja memberikan fokus penekanan pada teknik atau model tertentu. Metode audio-lingual misalnya, menekankan pentingnya peserta didik untuk menghafal contoh atau model percakapan sebelum kemudian menuju pada percakapan secara bebas. Sementara metode komunikatif menekankan pada pemahaman terkait percakapan, yakni memahami fungsi dari setiap kalimat dan konteks atau situasi yang melatarinya, dan kemudian secara langsung menuju latihan percakapan yang sebenarnya. ${ }^{5}$

Seiring dengan berkembangnya ilmu pengetahuan, terutama dalam bidang linguistik dan juga metodologi pembelajaran bahasa, mempelajari bahasa Arab kemudian menjadi sebuah hal yang semakin menantang. Di Indonesia, mengajar bahasa Arab memiliki tantangan dan permasalahan sendiri, hal tersebut dijelaskan oleh Samsudin Asrofi bahwa setidaknya ada tiga permasalahan dalam proses mengajar materi bahasa Arab di Indonesia yakni problem linguistik, metodologi, dan sosiologi. 6

Dari tiga pernyataan yang diajukan oleh Syamsuddin, proses belajar mengajar haruslah menjadi lebih menyenangkan, sehingga dalam hal ini guru membutuhkan metode media pembelajaran - untuk menyampaikan bahan ajar kepada siswa. Menurut beberapa ahli, media memiliki beberapa definisi sebagai berikut: (1) Media merupakan suatu teknologi yang digunakan oleh pengguna

\footnotetext{
${ }^{4}$ Nunu Mahnun, "Media pembelajaran (kajian terhadap langkah-langkah pemilihan media dan implementasinya dalam pembelajaran)," An-Nida' 37, no. 1 (2012): 27-34.

5 Nurmasyithah Syamaun, "Pembelajaran Maharah al-Kalam untuk Meningkatan Keterampilan Berbicara Mahasiswa Program Studi Pendidikan Bahasa Arab Fakultas Tarbiyah dan Keguruan," لساننا (LISANUNA): Jurnal Ilmu Bahasa Arab dan Pembelajarannya 4, no. 2 (2016): 343-59.

6 Syamsuddin Asyrofi, Metodologi Pengajaran Bahasa Arab: Konsep dan Implementasinya (Yogyakarta: Penerbit ombak, 2016).
} 
media dalam menyampaikan pesan; (2) Media (secara fisik) yang akan menyampaikan pesan, isi atau materi seperti slide, foto, kutipan buku dan lainlain; (3) Media merupakan alat untuk berkomunikasi dalam bentuk cetak dan juga audio-visual beserta perangkat kerasnya.

Media itu sendiri terdiri dari dua elemen, yakni perangkat keras atau alat dan juga perangkat lunak atau pesan. Media pembelajaran membutuhkan alat (harware) untuk mengirimkan materi yang berupa isi atau pesan (software). Sehingga yang disebut sebagai perangkat lunak merupakan bahan ajar atau materi yang akan diajarkan kepada siswa. Tetapi tidak semua media kemudian dapat dikatagorikan sebagai media pembelajaran. Media yang hanya berisi bahan ajar saja yang dapat disebut sebagai media pembelajaran. Misalnya, gambar yang tidak mengandung bahan ajar atau pesan untuk disampaikan pada siswa tentunya tidak bisa disebut sebagai media pembelajaran.

Media terbagi menjadi tiga dilihat dari sifatnya, antara lain media auditive, media visual, dan media audiovisual. Dalam penelitian ini, penulis akan menyampaikan penjelasan sebatas media visual. Media visual adalah media yang hanya bisa dilihat dan tidak ada elemen suara di dalamnya. ${ }^{7}$ Dalam proses pembelajaran bahasa Arab, ada berbagai media yang dapat digunakan, seperti komputer, hasil rekaman dalam Compact Disk (CD), media gambar dan lain sebagainya. Setiap media yang digunakan tentunya memiliki karakteristiknya tersendiri dan dapat memengaruhi proses pembelajaran siswa khususnya pada materi bahasa Arab. ${ }^{8}$

Alasan yang melandasi penelitian ini adalah untuk menambah khazanah studi mengenai implementasi media visual yang kemudian dapat dimanfaatkan dalam pembelajaran bahasa arab khususnya dalam kemampuan berbicara (maharoh al-kalam). Sebab tidak semua media visual dapat digunakan secara

7 Haris Budiman, "Penggunaan Media Visual dalam Proses Pembelajaran," AlTadzkiyyah: Jurnal Pendidikan Islam 7, no. 2 (2016): 171-82. 2009).

${ }^{8}$ Abdul Wahab Rosyidi, Media pembelajaran bahasa Arab (Malang: UIN-Maliki Press,

221 | Tarbiyatuna: Jurnal Pendidikan Ilmiah Vol. 5 No. 2 (Desember) 2020 
maksimal dalam pembelajaran maharoh al-kalam. Oleh karena itu penulis berharap dapat meneliti secara lebih mendalam terkait dengan pemanfaatan media visual yang dapat diimplementasikan dalam pembelajaran maharoh alkalam.

Penelitian ini merupakan penelitian pustaka dengan mencari berbagai literatur yang berkaitan dengan media pembelajaran, metodologi pengajaran bahasa Arab serta keterampilan berbicara dalam bahasa Arab. Metode penelitian yang digunakan adalah metode analisis deskriptif. Hal pertama yang akan dilakukan adalah mendeskripsikan atau memberikan deskripsi awal mengenai masalah yang akan dibahas. Kemudian yang kedua menganalisis berbagai data yang diperoleh dari berbagai literatur terkait dengan tema ini.

\section{B. Ketrampilan Berbicara Bahasa Arab}

Dalam perkembangannya, bahasa Arab kini telah menjadi salah satu bahasa internasional yang memungkinkan kita untuk menggunakan, berlatih serta mempelajari bahasa Arab sebagai bahasa kedua setelah bahasa ibu. Bahasa Arab dikenal sebagai bahasa dengan nilai kesusasteraan yang tinggi, memiliki daya tarik tersendiri dan mampu memikat perhatian para pengamat bahasa untuk mempelajarinya.

Pada abad pertengahan, bahasa Arab mulai menjadi alat utama dalam penyebaran ilmu pengetahuan dan sosial sehingga menyebabkan bahasa tersebut banyak menyerap kosakata dari berbagai bahasa lain. Bahasa Arab juga merupakan bahasa resmi dalam praktek beragama ummat Islam, dimana jumlah kaum muslimin di berbagai negara dunia selalu meningkat dari tahun ke tahun, hal ini kemudian menyebabkan bahasa Arab menjadi bahasa yang dipelajari secara luas dan di tuntut oleh hampir semua orang di dunia. Terdapat banyak sekali perangkat lunak, siaran televisi dan pembelajaran online dalam bahasa Arab. ${ }^{9}$

9 Rahmat Iswanto, "Pembelajaran Bahasa Arab Dengan Pemanfaatan Teknologi," Arabiyatuna: Jurnal Bahasa Arab 1, no. 2 (2017): 139-52. 
Dalam posisinya sebagai bahasa kedua, bahasa Arab memerlukan penyelarasan dan kontekstualisasi bahasa ke dalam bahasa ibu dalam proses belajar bahasa Arab untuk penutur asing. Sehingga sebagai salah satu cara ntuk membuat peserta didik menjadi lebih mudah dalam memahami makna yang sesuai dengan bahasa mereka maka bahasa Arab memerlukan proses pengkontekstualisasian. Dan dikarenakan kemajuan dari kehidupan pengguna bahasa di setiap periode maka hal tersebut menyebabkan perubahan etimologis yang dialami oleh setiap bahasa termasuk bahasa Arab. ${ }^{10}$

Seorang pendidik atau guru dalam mengajar bahasa asing haruslah memiliki berbagai metode atau berbagai cara yang dapat meningkatkan ketertarikan peserta didik dalam belajar. Salah satu cara yang dapat membuat siswa menjadi lebih tertarik adalah proses pembelajaran dengan menggunakan media pembelajaran. Media pembelajaran tentunya harus disesuaikan dengan situasi dan kondisi siswa.

Dalam hal ini kemudian memunculkan beberapa permasalahan dalam pengajaran bahasa Arab yaitu masalah linguistik, metodologi, dan sosiologi. Penggunaan metode yang tepat dapat membuat siswa lebih mudah menerima materi dan memiliki dampak positif pada hasil belajar siswa. Selain daripada optimalisasi hasil belajar, keakuratan metode dapat memengaruhi minat dan motivasi dalam diri siswa. ${ }^{11}$

Empat keterampilan berbahasa yang harus dikuasai oleh penutur asing dalam bahasa Arab antara lain adalah keterampilan menyimak (maharah alistima'), keterampilan membaca (maharah al-qira'ah), keterampilan menulis (maharah al-kitabah) serta keterampilan berbicara (maharah al-kalam).12 Sehingga kemudian penggunaan bahasa sebagai alat dalam komunikasi mampu

10 Umi Hanifah, Media pembelajaran bahasa Arab, Media Pembelajaran Bahasa Arab (Putra Media Nusantara, 2011).

11 Jauhar Ali, "Outbound as The Alternative Method to Have Fun Arabic Learning," ALSINATUNA 3, no. 2 (2018): 244-61.

12 Ahmad Zamroni, "Menjawab Kerancuan Kurikulum 2013 pada Mapel Bahasa Arab di Madrasah," At-Ta'lim: Jurnal Pendidikan 3, no. 1 (2017): 39-51. 
membuat penutur bahasa tersebut memahami teks serta konteks bahasa. Keahlian berbicara (maharatul kalam) merupakan keterampilan seseorang dalam pengucapan lafal suara Arab (ashwath 'arabiyyah) serta kalimat dengan tata linguistik (qawa'id an-nahwiyyah wa as-sharfiyyah) dalam penyampaian ide maupun perasaan.

Setiap keterampilan bahasa memiliki tingkat kemampuan yang meliputi performatif, fungsional, informasi, dan epistemis. ${ }^{13}$ Pada tingkat performatif, seseorang dapat memahami apa yang ia baca (fahm maqru'), mahir dalam menulis (kafa'ah kitabah), memahami apa yang disimak atau didengarkan (fahm masmu') dan juga mampu berbicara dengan simbol-simbol yang digunakan (al-kalam bi ramuz al-shauti). Kemudian di tingkat fungsional, seseorang telah mampu menggunakan bahasa kedua tersebut dengan tujuan untuk memenuhi kebutuhan meraka sehari-hari, seperti membaca surat kabar, menonton televisi dan mendengarkan podcast. Pada tingkat informatif, seseorang dengan keterampilan bahasa kedua telah mampu menggunakan bahasa kedua tersebut dalam mengakses pengetahuan. Sedangkan pada level epistemik, seseorang mampu mengekspresikan pengetahuan serta perasaannya ke dalam bahasa kedua.

Manusia adalah makhluk sosial, salah satu sikap terpenting dalam ranah sosial adalah berkomunikasi. Di dalam komunikasi ada proses bertukar pengalaman, mengekspresikan dan menerima ide atau perasaan, saling bertukar gagasan mengenai keyakinan. Sehingga dari sini, keterampilan berbicara yang mencakup kemampuan dalam menguasai artikulasi, juga merupakan hal yang penting dalam kehidupan manusia. ${ }^{14}$

Maharah al-kalam adalah kemampuan untuk menuturkan suara artikulatif atau kata-kata yang bertujuan untuk mengekspresikan pikiran dalam bentuk ide, pendapat, keinginan, atau perasaan kepada orang lain. Selain itu, esensi daripada

13 NISFUL SUAIDAH, "Pengembangan Media Pembelajaran Berbasis Adobe Flash CS3 dalam Kemahiran Kalam untuk Siswa Kelas VII SMP Darul Quran Singosari Malang," SKRIPSI Jurusan Sastra Arab-Fakultas Sastra UM, 2011.

14 Rahmaini Rahmaini, "Strategi Pembelajaran Maharah Kalam Bagi Non Arab," Ihya al-Arabiyah: Jurnal Pendidikan Bahasa dan Sastra Arab 1, no. 2 (2015). 
maharah al-kalam adalah keterampilan menggunakan bahasa pada tingkatan yang rumit.15 Keterampilan berbicara ini membutuhkan keterlibatan pikiran dan perasaan serta keterampilan mendengarkan sehingga percakapan dapat berlangsung dengan lancar.

Kalam secara terminologi berasal dari bahasa Arab al-kalam yang memiliki arti 'kata-kata atau ucapan'. Secara etimologi, kalam merupakan pengucapan suara bahasa Arab secara baik, benar serta sejalan dengan aturan suara dalam linguistik. Sehingga maharah al-kalam artinya adalah kemampuan dalam berbicara secara lancar dan tidak mengulang-ulang perbendaharaan kata yang sama. ${ }^{16}$

Era revolusi industri 4.0 yang tengah berlangsung mengharuskan seorang guru dalam meningkatkan kreatifitas serta inovasi dengan tujuan untuk membuat peserta didik dapat fokus dan memusatkan perhatiannya dalam proses pembelajaran. Suatu ciri khas yang nampak dimiliki oleh generasi sekarang yaitu adanya ketertarikan kepada hal-hal yang bersifat visual. Sehingga pemanfaatan media visual akan membawa dampak yang positif dalam proses pembelajaran apabila digunakan secara optimal dan efektif. Sebagaimana hasil penelitian yang telah dilakukan oleh Riska bahwasanya pemanfatan media visual dapat meningkatkan hasil belajar bahasa arab melalui Metode al-Qawaid wa-Tarjamah pada siswa kelas IV MIN Kolomayan Wonodadi Blitar tahun ajaran 2013-2014.17

Sama seperti halnya dalam proses pembelajaran materi-materi pelajaran secara umum, dalam pembelajaran bahasa Arab media memiliki peran yang penting. Salah satu perannya adalah membantu guru dalam mempermudah penyampaian dan penjelasan materi kepada para siswa. Guru merupakan media utama dalam pembelajaran karena siswa melihat dan mendengar materi secara

15 Sahkholid Nasution, "Tadris Maharah Al-Kalam Fi Madrasah Tsunaiyyah AlLughah Al-Stanawiyah," Lingua: Jurnal Ilmu Bahasa Dan Sastra 10, no. 2 (2015): 97-108.

16 Rizania Firdayanti, "Permasalahan Belajar Maharah Kalam pada Mahasiswa Semester 3 Jurusan Sastra Arab Universitas Negeri Malang dan Solusinya," SKRIPSI Jurusan Sastra Arab-Fakultas Sastra UM, 2018.

17 Puspita Devi Riska, "Peningkatan Hasil Belajar Bahasa Arab melalui Metode alQawaid wa-Tarjamah menggunakan Media Visual Gambar bagi Siswa Kelas IV MIN Kolomayan Wonodadi Blitar Tahun Ajaran 2013-2014," 2014. 
langsung melalui guru, dan dalam kondisi tertentu media pembelajaran kemudian menjadi model / media utama dalam pembelajaran sedangkan guru atau pendidik hanya berperan sebagai pelengkap untuk menambahkan penjelasan dari media. ${ }^{18}$

Berdasarkan penjelasan di atas, media visual dapat dimanfaatkan dalam proses belajar materi-materi bahasa Arab karena peserta didik yang sekarangf termasuk dalam generasi milenial memiliki ketertarikan akan hal tersebut. Berbagai jenis media visual dapat menjadi pilihan oleh seorang guru. Namun dalam pemilihan media, ada hal yang harus dipertimbangkan oleh guru yakni materi yang akan disampaikan dan latihan-latihan yang akan ditugaskan kepada siswa, sehingga pemilihan media dapat dimanfaatkan sesuai kebutuhan siswa.

Secara khusus media visual memiliki beberapa fungsi antara lain adalah untuk menarik perhatian, memperjelas dalam menyampaikan ide, menggambarkan sebuah materi yang apabila tidak divisualisasikan kemungkinan akan mudah terlupakan. Siswa juga lebih tertarik pada media visual, terutama yang memiliki beragam pilihan, sederhana, dan terlihat nyata. Selain itu dengan menggunakan media visual, atmosfir atau suasana belajar dalam kelas akan terasa lebih menyenangkan dan lebih menarik bagi guru dan juga siswa. ${ }^{19}$

Media visual terbagi menjadi enam kategori yakni realistis, analogis, organisasi, relasional, transformasional, dan interpretatif: 20

a. Realistis artinya adalah realitas visual yang ditampilkan atau menampilkan objek secara nyata dari objek yang sedang dipelajari. Misalnya menampilkan gambar maktabah (perpustakaan) dalam materi membaca.

18 Muhammad Wafaul Himam dkk., "ROLLING BALL: PENGEMBANGAN MEDIA PEMBELAJARAN KETERAMPILAN BERBICARA BAHASA ARAB KELAS VIII MTs DI KABUPATEN PEKALONGAN," Lisanul'Arab: Journal of Arabic Learning and Teaching 6, no. 1 (2017): 50-55.

19 Ahmad Nurcholis, "Penggunaan Thariqah Mubasyarah dengan Media Visual Gambar untuk Meningkatkan Prestasi Belajar Bahasa Arab Siswa Kelas III MI Muhammadiyah Siyotobagus Besuki Tulungagung," 2014.

${ }^{20}$ Nurul Fauziyah, "Penggunaan Media Visual dalam Pembelajaran Bahasa Arab di MI Ma'arif NU 1 Sokaraja Tengah Sokaraja Banyumas” (IAIN, 2016). 
b. Analogis adalah penyampaian pesan, konsep, atau topik kepada siswa dengan menunjukkan atau memvisualisasikan hal lain yang mirip atau serupa dengan pesan tersebut.

c. Organisasi adalah menampilkan sistem diagram terstruktur yang berkaitan antara satu sama lain, sebagai elemen kesatuan. Seperti bagan klasifikasi, kaidah, alur, dan peta. contohnya dalam bahasa Arab adalah klasifikasi kalimah (kata) berupa isim (kata benda), fi il (kata kerja) dan huruf (huruf yang memiliki arti). Pengorganisasiaan klasifikasi tersebut ke dalam diagram yang terstruktur akan membuat siswa menjadi lebih faham dan mudah dalam mengingat materi tersebut.

d. Relasional visual adalah media visual yang menampilkan hubungan kuantitatif. Seperti bentuk diagram lingkaran dan batang, grafik garis dan grafik bergambar.

e. Transformasional yaitu metode visual yang menggambarkan perubahan berdasarkan konteks waktu dan tempat. Dalam belajar bahasa Arab, seorang guru dapat membuat diagram transformasional ketika menjelaskan proses penurunan Al-Qur'an.

f. Interpretatif merupakan media yang akan menggambarkan hubungan teoritis dan abstrak. Dalam bahasa arab dapat dijadikan contoh adalah rangkaian kalimat jumlah fi liyyah dan jumlah ismiyyah.

\section{Prinsip Penggunaan Media Visual}

Pada pemanfaatannya yang dapat membuat implementasi dari media visual menjadi lebih efektif dalam proses pembelajaran, penggunaan media ini hendaknya memperhatikan beberapa prinsip: (1) Penyederhanaan visual dengan grafik, diagram atau garis; (2) Menggunakan metode visual sebagai sarana untuk meringkas informasi; (3) Penggunaan grafik sebagai kesimpulan pada sebuah materi pelajaran; (4) Melakukan repetisi visual dengan melibatkan siswa; (5) Penggunaan gambar untuk membedakan suatu konsep dengan konsep yang lain; 
(6) Penggunaan visual harus berimbang; (7) Semua visual harus jelas dan tepat;

(8) Menggunakan warna yang mudah diingat; (9) Penyampaian gambar yang mengandung teks penjelasan.

\section{Panduan Mendesain Media Visual}

Dalam membuat media visual, seorang guru harus tahu tentang pedoman dasar bagaimana merancang visual yang baik. Ini bertujuan untuk merancang media visual secara efektif sehingga dapat menarik minat dan perhatian siswa dan juga mempermudah dalam memahami materi. Terdapat dua aspek desain visual, kedua aspek tersebut adalah aspek visual (berupa foto, gambar dan grafik) dan juga elemen teks. Untuk mendesain suatu gambar visual kita ada lima hal yang harus diperhatikan dan dipertimbangkan, ke lima hal tersebut terdiri dari arrangement (pengaturan), balance (keseimbangan), colour (pewarnaan), legibility (keterbacaan), dan appeal (daya tarik).

a. Arrangement (pengaturan gambar) yang meliputi kesejajaran gambar dan kesetaraannya terhadap elemen gambar yang lain; Bentuk gambar tersebut; Rule of third, yakni sebuah prinsip tata letak poin fokus sebuah gambar yang harus digunakan terutama pada bidang fotografi, aturan ini berbeda-beda antara pemandangan alam, objek berupa mahluk hidup dan juga objek yang bergerak; Kedekatan (proximity) mendefinisikan cara pandang manusia, karena kita secara tidak sadar melihat suatu objek berdasarkan kedekatan itu; Arah (directional), yakni memperhatikan ke mana sebuah objek mengarah; Kontras antara objek dengan latar belakang, kontras yang baik akan semakin menonjolkan objek yang ingin ditampilkan.

b. Balance (keseimbangan) yang berarti apabila terdapat beberapa objek atau media visual yang kita gunakan, maka keseimbangan di antaranya harus diperhatikan. Contohnya apabila terdapat tiga gambar visual yang kita gunakan maka ketiganya harus memiliki proporsionalitas yang seimbang. 
c. Colour (pewarnaan), yakni pemilihan warna perlu diperhatikan dan perlu ketelitian agar gambar visual memberikan kesan yang harmonis. Penggunaan warna yang baik juga akan meningkatkan kemudahan dalam memahami materi yang terkandung dalam gambar visual. Warna yang dipilih untuk menampilkan latar belakang dan objek juga harus menggunakan warna yang tepat. Penggunakan warna dalam bahan pembelajaran juga berfungsi: Untuk menambah kesan realitas atau fakta kongkrit; Untuk menunjukkan berbagai elemen yang berbeda dari gambar visual; Untuk memfokuskan sebuah objek yang dimaksud; Untuk mengkodifikasi antar elemen dalam gambar; Untuk menarik perhatian; Dan untuk menggambarkan emosi serta responnya. ${ }^{21}$

d. Legibility (keterbacaan) yang artinya dalam pembuatan sebuah media visual perlu memperhatikan keterbacaan antar elemen oleh peserta didik. Apakah pembaca mampu memahami konten dan elemen yang kita buat atau belum, dan bagaimana tingkat keterbacaan dari konten dan elemen dari jarak terjauh kemungkinan terdapatnya pembaca, contohnya untuk membuat media tersebut sebagai media pembelajaran di dalam kelas maka media harus terlihat jelas hingga oleh siswa yang duduk di bangku paling belakang. Dan tingkat keterbacaan ini dapat juga dibantu dengan elemen lainnya seperti kontras warna.

e. Appeal (daya tarik) yakni upaya untuk memaksimalkan konten dan materi visual dengan memanfaatkan ide-ide kreatif, inofatif dengan tujuan memunculkan daya tarik pada materi visual tersebut. Daya tarik ini juga tergantung dengan target pembaca yang dituju. Misalnya ketika mendesain media visul untuk anak-anak, maka garis desainya imajinatif, menggunakan warna-warna terang dan variatif. Apabila desain visual ditujukan untuk remaja maka menggunakan bahasa desain yang realistis, lugas dan dengan warna-

${ }^{21}$ Sigit Purnama, "Elemen warna dalam pengembangan multimedia pembelajaran agama Islam," Al-Bidayah: Jurnal Pendidikan Dasar Islam 2, no. 1 (2010). 
warna yang harmonis. Sedangkan untuk orang-orang dewasa menggunakan gaya desain yang minimalis.

Dalam tampilan visual, seorang guru tidak hanya menampilkan gambar namun juga termasuk informasi dalam bentuk teks. Teks pada media yang akan ditampilkan juga memiliki prinsip-prinsip sendiri, termasuk di antaranya adalah gaya, ukuran, spasi dan warna.

a. Gaya. Untuk tujuan pengajaran, pembelajaran atau informasi yang disampaikan, tulisan yang dipilih harus konsisten, gaya teks yang minimalis (tidak ada hiasan yang mencolok), dan berisi tulisan yang sederhana. Contohnya adalah memilih font bergaya sans serif, yakni jenis huruf yang tampilannya terkesan solid dan tampak tegas, tidak mempunyai garis-garis kecil sebagai hiasan. Font ini bersifat fungsional dan juga terlihat lebih modern. Beberapa contoh dari font yang termasuk dari jenis sans serif yaitu Century Ghotic, Futura, Helvetica (1957), Arial dan sebagainya.

b. Ukuran. Pemilihan ukuran juga erat kaitannya dengan keterbacaan. Dengan memperhatikan posisi terjauh dari siswa yang akan dituju. Sehingga apabila gambar visual akan ditampilkan dalam kelas, maka ukuran huruf harus dapat terbaca oleh siswa yang duduk di bagian paling belakang.

c. Spasi. Ada dua hal dalam menentukan spasi atau jarak, yakni jarak antara huruf satu dengan yang lain juga jarak antara baris ke baris. Ruang antara setiap huruf harus memperhatikan jarak optik, yakni jarak yang memungkinkan setiap mata mampu melihat dengan jelas, sedangkan ruang vertikal di antara setiap baris harus memperhitungkan agar tidak terlalu berdekatan dan juga tidak terlalu renggang.

d. Warna. Penentuan warna yang akan digunakan dalam teks pada media pembelajaran juga harus kontras dengan latar belakangnya supaya meningkatkan kemudahan dalam membaca teks tersebut. 


\section{Implementasi Media Visual Pada Keterampilan Berbicara}

Dalam proses pembelajaran keterampilan berbicara, guru perlu mengetahui dan memperhatikan tingkat kemampuan yang dimiliki oleh siswa, apa kekurangan yang harus diperbaiki dan juga kelebihan yang harus dipertahankan, sehingga guru dapat menentukan materi apa yang akan disampaikan kepada siswa. Yang diharapkan dari hasil pembelajaran kemampuan berbicara ini adalah siswa mampu menggunakan bahasa secara aktif dalam komunikasi, karena berkomunikasi merupakan salah satu tujuan berbahasa. Dalam istilah linguistik, pesan lisan yang disampaikan melalui berbicara haruslah sesuai antara penggunaan kata-kata yang dipilih dengan dengan ide atau perasaan yang ingin disampaikan. Kata-kata tersebut diatur sesuai dengan kaidah tata bahasa (nahwu) dan dibacakan sesuai dengan aturan pengucapan (shout) yang tepat. Semua aspek bahasa adalah bagian dari kegiatan berbicara sebagai bentuk bahasa lisan. Pembicara harus dapat berusaha agar pesan yang disampaikan dapat dipahami oleh pendengar sebagaimana dimaksud oleh pembicara. Media visual yang dapat digunakan dalam pembelajaran kalam meliputi: poster, papan flanel, gambar, papan buletin.

\section{Poster}

Poster merupakan media visual dengan presentasi yang nampak mencolok, jelas, dan menarik yang bertujuan untuk meningkatkan ketertarikan serta perhatian setiap orang yang sedang melewatinya. Poster juga dapat berpengaruh terhadap sikap, perilaku dan nilai-nilai masyarakat untuk mengubah atau melakukan sebuah hal. Media poster ini dapat digunakan untuk kepentingan belajar, yang sengaja dipasang di luar, ataupun di dalam kelas. Dalam proses belajar bahasa Arab khususnya maharah kalam, media poster ini dapat digunakan dalam menyampaikan materi kalam melalui media tersebut. Dalam penggunaannya, guru pertama-tama memilih topik yang akan disajikan, kemudian mencari / membuat poster yang berkaitan dengan topik yang akan disajikan, 
selain itu poster yang digunakan ini juga harus selaras dan sesuai dengan materi yang disampaikan.

\section{Papan Flanel}

Media pembelajaran ini berupa papan yang dilapisi flanel untuk menyampaikan kata-kata atau gambar yang mudah dalam pemasangannya dan juga mudah dalam pelepasannya. Alat ini terbuat dari kain flanel berwarna yang dipasang di dinding atau dijapit menggunakan dua potong kayu di bagan bawah dan atasnya kemudian digantung. Gambar dipasang di kain flanel, bagian belakang gambar direkatkan agar mudah ditempel dan dilepas. Melalui alat ini, berbagai gambar seperti pakaian, binatang, buah-buahan, anggota keluarga dan lainnya dapat ditampilkan dengan jelas. Papan flanel termasuk dalam katagori media pembelajaran visual berbasis dua dimensi, dan papan flanel juga merupakan media visual yang efektif dalam penyampaian pesan ataupun materi kepada target peserta didik.

Kelebihan dalam penggunaan papan flanel adalah media gambar yang terdapat di dalamnya mudah dalam pemasangan dan pelepasannya sehingga menambah efisiensi waktu dan energi. Media ini juga dapat menarik perhatian siswa sehingga memudahkan guru untuk menjelaskan materi.

\section{Papan Buletin}

Papan buletin adalah papan biasa yang dilapisi dengan kain flanel. Gambar dan tulisan bisa langsung dilampirkan menggunakan lem atau alat tempel lainnya. Papan buletin banyak digunakan di universitas sebagai media pembelajaran yang dapat meningkatkan keterampilan kalam. Media ini digunakan untuk melakukan kegiatan pembelajaran bahasa, sehingga siswa yang tidak berpartisipasi dalam buletin akan tertinggal. Buletin dikelola dengan baik dan profesional, sehingga dapat menarik dan membantu dalam belajar bahasa Arab (kalam). Penggunaan papan buletin dapat dilakukan dengan melampirkan kliping dari koran berbahasa 
Arab atau majalah berbahasa Arab, dengan mempertimbangkan poin-poin berikut: a) Kliping harus diatur dan dirancang dengan rapi; b)Gunakan tulisan berwarna; c) Siswa didorong untuk membacanya untuk mengetahui apa yang terjadi; d) Tampilan ornamen harus diganti agar terlihat segar dan kliping terbaru.

\section{Gambar}

Media visual berupa gambar terdapat beberapa jenis, antara lain adalah: Foto, yakni media visual hasil dari proses fotografi; Lukisan, yaitu media visual berupa karya seni lukis menggunakan tangan; Dan ilustrasi yang merupakan karya visual hasil dari proses editing digital menggunakan komputer atau yang terkenal dengan istilah digital art (seni digital). Baik foto, lukisan maupun karya seni digital tersebut berfungsi sebagai pembawa materi dalam pembelajaran. Gambar yang diletakkan di depan kelas harus menyesuaikan ukurannya sehingga gambar tersebut tampak jelas sehingga mudah dilihat oleh siswa. Adanya gambar tidak menjamin perhatian siswa, oleh karena itu guru harus mampu mengondisikan siswa supaya tetap aktif dan juga guru harus menjelaskan kepada siswa tentang apa yang perlu diperhatikan.

Dalam belajar bahasa Arab, gambar media ini dapat digunakan sebagai topik pembicaraan. Biasanya dalam proses pembelajaran, guru menyampaikan materi tentang suatu topik menggunakan metode cerita dan kemudian mengajukan pertanyaan dan jawaban. Terkadang siswa kurang tertarik jika mereka hanya mendengarkan cerita, tetapi dengan gambar ini para peserta akan lebih tertarik mendengarkan cerita dan memegang jawaban. Media gambar ini dikombinasikan dengan metode cerita dan tanya jawab, sehingga implementasinya dalam pembelajaran bahasa Arab menjadi lebih efektif.

\section{Media Jam}

Menurut Abd Wahab Rosyidi, jam adalah media yang paling sukses dalam belajar bahasa Arab. Media ini dibuat dan diperoleh oleh seorang guru, biasanya 
terdiri dari angka 1-12, terdapat jarum panjang, jarum sedang dan jarum pendek. Namun, sebelum menggunakan media jam ini, harus dipastikan bahwa peserta sudah menguasai hitungan satu hingga enam puluh. Langkah selanjutnya adalah guru memutar jam seperti biasa, setelah memastikan jam menunjukkan angka tertentu, guru mengajukan berbagai pertanyaan.

\section{Kesimpulan}

Dari pembahasan di atas dapat dilihat bahwa dalam menggunakan media pembelajaran berbasis visual / media pembelajaran terdapat berbagai macam aturan. Pengaturan yang ada dibuat dengan tujuan memanfaatkan media visual secara efektif dalam pembelajaran. Penggunaan media yang baik akan mempengaruhi keberhasilan atau kegagalan penyampaian pesan (materi pembelajaran) kepada siswa. Media visual yang dimaksud adalah media yang hanya bisa dilihat, tanpa elemen suara. Jenis visualnya realistis, analog, organisasional, relasional, transformasional, dan interpretatif. Selain itu, ada prinsip dalam penggunaan media visual termasuk kesederhanaan yang disarankan, kejelasan, keterbacaan, dan lainnya. Panduan desain visual memiliki dua elemen, yaitu elemen visual dan elemen teks. Elemen visual meliputi lima hal, yaitu pengaturan, keseimbangan, warna, keterbacaan dan daya tarik. Selanjutnya, elemen teks termasuk gaya, ukuran, ruang, warna dan penggunaan huruf besar. Yang perlu dipertimbangkan dalam menggunakan gambar sebagai bentuk media visual adalah alat perencanaan, teknik pembuatan gambar, membuat sketsa, membuat kartun, clip art, merancang visual dengan komputer, membuat grafik presentasi, membuat proyektor overhead ( OHP). Selain itu, dalam pengambilan gambar ada juga dua cara, yaitu fotografi dan pemindai.

Dalam implementasinya, media visual dapat diimplementasikan dalam pembelajaran bahasa Arab, salah satunya adalah pembelajaran kalam. Media visual yang dapat digunakan meliputi gambar, poster, papan flanel, papan buletin, dan jam. Jenis media visual ini adalah salah satu media yang dapat digunakan 
dalam pembelajaran bahasa Arab, sehingga pembelajaran bahasa Arab dapat berhasil.

\section{Daftar Rujukan}

Ali, Jauhar. "Outbound as The Alternative Method to Have Fun Arabic Learning." ALSINATUNA 3, no. 2 (2018): 244-61.

Asyrofi, Syamsuddin. Metodologi Pengajaran Bahasa Arab: Konsep dan Implementasinya. Yogyakarta: Penerbit ombak, 2016.

Budiman, Haris. "Penggunaan Media Visual dalam Proses Pembelajaran." AlTadzkiyyah: Jurnal Pendidikan Islam 7, no. 2 (2016): 171-82.

Fauziyah, Nurul. "Penggunaan Media Visual dalam Pembelajaran Bahasa Arab di MI Ma'arif NU 1 Sokaraja Tengah Sokaraja Banyumas.” IAIN, 2016.

Firdayanti, Rizania. "Permasalahan Belajar Maharah Kalam pada Mahasiswa Semester 3 Jurusan Sastra Arab Universitas Negeri Malang dan Solusinya." SKRIPSI Jurusan Sastra Arab-Fakultas Sastra UM, 2018.

Hanifah, Umi. Media pembelajaran bahasa Arab. Media Pembelajaran Bahasa Arab. Putra Media Nusantara, 2011.

Himam, Muhammad Wafaul, Laela Mufida, Zukhaira Zukhaira, dan Ahmad Miftahudin. "ROLLING BALL: PENGEMBANGAN MEDIA PEMBELAJARAN KETERAMPILAN BERBICARA BAHASA ARAB KELAS VIII MTs DI KABUPATEN PEKALONGAN." Lisanul'Arab: Journal of Arabic Learning and Teaching 6, no. 1 (2017): 50-55.

Iswanto, Rahmat. "Pembelajaran Bahasa Arab Dengan Pemanfaatan Teknologi." Arabiyatuna: Jurnal Bahasa Arab 1, no. 2 (2017): 139-52.

Mahnun, Nunu. "Media pembelajaran (kajian terhadap langkah-langkah pemilihan media dan implementasinya dalam pembelajaran)." An-Nida' 37, no. 1 (2012): 27-34.

Muhson, Ali. "Pengembangan media pembelajaran berbasis teknologi informasi." Jurnal Pendidikan Akuntansi Indonesia 8, no. 2 (2010). 
Mustofa, Syaiful. Strategi Pembelajaran Bahasa Arab Inovatif. Malang: UIN-Maliki Press, 2011.

Nasution, Sahkholid. "Tadris Maharah Al-Kalam Fi Madrasah Tsunaiyyah AlLughah Al-Stanawiyah." Lingua: Jurnal Ilmu Bahasa Dan Sastra 10, no. 2 (2015): 97-108.

Nugrawiyati, Jepri. "Media Audio-Visual Dalam Pembelajaran Bahasa Arab." ElWasathiya: Jurnal Studi Agama 6, no. 1 (2018): 97-111.

Nurcholis, Ahmad. "Penggunaan Thariqah Mubasyarah dengan Media Visual Gambar untuk Meningkatkan Prestasi Belajar Bahasa Arab Siswa Kelas III MI Muhammadiyah Siyotobagus Besuki Tulungagung," 2014.

Purnama, Sigit. "Elemen warna dalam pengembangan multimedia pembelajaran agama Islam." Al-Bidayah: Jurnal Pendidikan Dasar Islam 2, no. 1 (2010).

Rahmaini, Rahmaini. "Strategi Pembelajaran Maharah Kalam Bagi Non Arab." Ihya al-Arabiyah: Jurnal Pendidikan Bahasa dan Sastra Arab 1, no. 2 (2015).

Riska, Puspita Devi. “Peningkatan Hasil Belajar Bahasa Arab melalui Metode alQawaid wa-Tarjamah menggunakan Media Visual Gambar bagi Siswa Kelas IV MIN Kolomayan Wonodadi Blitar Tahun Ajaran 2013-2014,” 2014.

Rosyidi, Abdul Wahab. Media pembelajaran bahasa Arab. Malang: UIN-Maliki Press, 2009.

SUAIDAH, NISFUL. "Pengembangan Media Pembelajaran Berbasis Adobe Flash CS3 dalam Kemahiran Kalam untuk Siswa Kelas VII SMP Darul Quran Singosari Malang." SKRIPSI Jurusan Sastra Arab-Fakultas Sastra UM, 2011.

Syamaun, Nurmasyithah. "Pembelajaran Maharah al-Kalam untuk Meningkatan Keterampilan Berbicara Mahasiswa Program Studi Pendidikan Bahasa Arab Fakultas Tarbiyah dan Keguruan." لسـانـL (LISANUNA): Jurnal Ilmu Bahasa Arab dan Pembelajarannya 4, no. 2 (2016): 343-59.

Zamroni, Ahmad. “Menjawab Kerancuan Kurikulum 2013 pada Mapel Bahasa Arab di Madrasah." At-Ta'lim: Jurnal Pendidikan 3, no. 1 (2017): 39-51. 